\title{
A Cyclist's Heart
}

\section{Glenn C Newell*}

Department of Medicine, Cooper University Hospital, Camden, New Jersey, USA

*Corresponding author: Glenn C Newell, Department of Medicine, Cooper University Hospital, Camden , New Jersey, USA, Tel: 6092067411; E-mail: newellglenn@cooperhealth.edu

Received date: August 21, 2017; Accepted date: August 24, 2017; Published date: August 26, 2017

Copyright: (C) 2017 Newell GC. This is an open access article distributed under the terms of the Creative Commons Attribution License, which permits unrestricted use, distribution, and reproduction in any medium, provided the original author and source are credited.

Keywords: Coronary disease; Cholesterol; Multiple sclerosis

\section{Short Communication}

Most everyone in the hospital where I worked was shocked. After all I was known as the doctor who rode his bike to work.

I was 48 years old at the time. I had a wife, kid, great job as an internist at a university hospital and was an avid amateur competitive cyclist and in great fitness-and I thought great health.

I started to notice when I would begin a ride a burning sensation in my throat and a deep ache in the palm of my hands. I thought at first that the throat burning was due to the recent sanding of the floors in my house and that the hand ache was that my cycling gloves were too tight. I offhandedly told my wife I was having these symptoms. She said get a stress test. I thought she was wrong-so I went to my Chief of Medicine who said "Glenn you are the healthiest guy I know, but when the wife says get a stress test then get one"!

Long story short the stress test was stopped at two minutes as I saw my EKG's ST Segments drop and I had the familiar throat and palm pain (mind you I never had any chest pain). An emergent coronary catheterization a few hours later showed severe coronary artery disease and the next morning I was getting my chest cracked open for quintuple bypass.

So what caused this? Why me? My mom and dad both lived to over 90 -years old with no evidence of coronary disease. My cholesterol was decent at about $200 \mathrm{mg} / \mathrm{dl}$, but I was a bad eater throughout my childhood and adult years, for example 2 burgers and a hot dog for dinner. Never one slice of pizza, usually 3 maybe more. I remember eating a pint of Hagen Daaz ice cream each night of the 1986 World Series when I watched the Mets beat the Redsoxs. I stayed thin however from cycling.

At the time I did have a thirty year history of chronic hepatitis $\mathrm{C}$ from a childhood blood transfusion (subsequently cured). Though controversial, hepatitis $\mathrm{C}$ has been shown in several studies to be a risk factor for atherosclerosis $[1,2]$. Within a month I was back on the bike and by three months "hammering" on the bike again and for a while super diligent about my diet. That was almost over fourteen years ago and the dietary diligence faded as I once again felt strong and indestructible. Certainly I was a better eater than in my 30's and 40's and was on cholesterol medication and aspirin and actually was over ten pounds lighter than when I had my bypass. But the bad eating habits returned-stress eating at work: chicken nuggets to justify a tough afternoon of clinic, the extra burger, never just one slice of pizza, a dish of ice cream before bed (yes smaller) while watching the Tour de France.

Then at age 61 the sensation in the throat with exertion returned. I hammered through it on the bike doing one of my workouts with high intensity intervals (HIT). I figured again it was nothing. Then on the next ride it happened again. Now scared, I called my cardiologist and scheduled another stress test. When I got the results I nearly cried, the inferior wall of the heart was not getting enough blood flow and there was both a small area of infarction as well as ischemia. I had cycled through a myocardial infarction. The subsequent cardiac catheterization results were about as good as I could have hoped: the small vein grafts to the inferior part of my heart had occluded, not too unusual and corollary arteries were already starting to grow and perfuse that area.

Did regression to poor dietary choices cause my recent blockages? Vein grafts are known to occlude as years go on [3]. My cholesterol was good at about $170 \mathrm{mg} / \mathrm{dl}$ but my LDL ran slightly above $100 \mathrm{mg} / \mathrm{dl}$. I ignored my cardiologist's advice to drive my LDL lower with drugs, convinced that the studies that have proven the benefit of more drastic LDL reduction just didn't apply to a fit thin person like me. However, I am convinced that diet was part of the issue. Just like with bike parts some maintenance and non-abuse makes it all last longer.

The story of a young fit individual who has severe coronary disease is not that unusual. Boston Marathon Director Dave McGillivray had been a dedicated runner his whole life, even running his age in miles every year on his birthday starting at age 12 and even now in his 60's. By his own admission he was a bad eater as well. He began to have some exertional symptoms and was told a few months after the marathon bombing he had severe coronary disease My cardiologist says he sees several similar cases a year and unfortunately we probably all know of a young super fit athlete who dies suddenly (think running guru Jim Fixx). It just happened to a 45-years old cyclist during one of the local South Jersey group rides.

So what am I doing now about my coronary atherosclerosis? In many ways I am taking the lead of my friend and patient Bob Cafarocellist with the Philadelphia Orchestra who miraculously cured himself from Multiple Sclerosis. How did he do it? As he outlines in his book "When the Music Stopped" he combined allopathic medicine with strict dietary control, meditation, yogic breathing and other techniques [4]. Hard to believe I know but the complete regression of his cortical and cervical spine MS plaques and the total reversal from near disability to normal functioning is clearly well documented and cannot be denied.

So why share my medical history? What have I learned from my story? First do not be fooled by fitness alone. As noted fitness does not always equal health. Fitness as well can often mask otherwise important symptoms. Recently a cycling friend's symptoms of falling off the back in his 30 mile group rides was disregarded by his primary care physician who was just impressed that he could ride that far at all. He turned out to have Hodgkin's disease. If you are caring for athletesprofessionals, dedicated amateurs or weekend warriors-be cautious and believe their symptoms, especially if exertional. 
Eat healthy and be an example to your patients. And for any of you or your patients with a story similar mine stay even more diligent with eating, medications if needed and follow up with your care provider. To paraphrase Dave McGillivray-you don't have to become one of those vegetarian guerillas. Just cut out the junk! And most importantly, if your spouse says get a stress test, then get one!

\section{References}

1. Vassalle C, Masini S, Bianchi F, Zucchell GC (2004) Evidence for association between hepatitis $C$ virus seropositivity and coronary artery disease. Heart 90: 565-566.
2. Butt AA, Xiaoqiang W, Budoff M, Leaf D, Justice AC (2009) Hepatitis C virus infection and the risk of coronary disease. Clin Infect Dis 49: $225-232$.

3. Fitzgibbon GM, Kafka HP, Leach AJ, Keon WJ, Hooper GD, et al. (1996) Coronary bypass graft fate and patient outcome: Angiographic follow-up of 5,065 grafts related to survival and reoperation in 1,388 patients during 25 years. J Am Coll Cardiol 28: 616-626.

4. Cafaro B (2015) When the music stopped. My battle and victory against MS. (2 $\left.2^{\text {nd }} e d n\right)$. 